\section{Prevalence and risk factors of gastrointestinal parasites in sheep from Ubaté, Cundinamarca, Colombia}

\author{
Prevalência e fatores de risco de infecções por helmintos em \\ ovelhas de Ubaté, Cundinamarca, Colômbia
}

\begin{abstract}
Martín Orlando Pulido-Medellín' (D), Ginette Isabel Chavarro-Tulcán² \& Adriana María Díaz-Anaya* (D)
'Veterinarian, MSc. Faculty of Veterinary Medicine and Zootechnics, Research group in Veterinary Medicine and Zootechnics GIDIMEVETZ, Universidad Pedagógica y Tecnológica de Colombia - UPTC, Tunja, Colombia

${ }^{2}$ Veterinarian, Esp. Research group in Veterinary Medicine and Zootechnics - GIDIMEVETZ. Universidad Pedagógica y Tecnológica de Colombia - UPTC, Tunja, Colombia.

${ }^{3}$ Veterinarian, MSc. Research group in Veterinary Medicine and Zootechnics - GIDIMEVETZ, Universidad Pedagógica y Tecnológica de Colombia - UPTC, Tunja, Colombia
\end{abstract}

\begin{abstract}
Sheep production is considered an important sector of meat supply for human consumption and contributes to development of the rural areas. Gastrointestinal infection in sheep include helminthic and coccidial infections and in order to establishing preventive measures against parasites in flocks, an understanding of its epidemiology is required. The aim of this study was to determine the prevalence of helminthic and coccidial infections in sheep from Ubaté - Colombia by Ritchie concentration method and to identify the risk factors (sex, feeding, age, physiological state and deworming condition) associated with infection. 400 fecal samples were collected using a convenience sampling method. Risk factors were analyzed by logistic regression analysis. Risk was expressed as an odds ratio (OR) with 95\% confidence interval. Descriptive epidemiology and risk factors were performed using EpiInfo software. The overall prevalence was 78.1\%. The different families observed were Dictyocaulidae (43.5\%), Trichostrongylidae (32.7\%), Ascaridae (2.8\%), Trichuridae (3\%), Chabertiidae (39.7\%), Fasciolidae (0.4\%), Eimeriidae (93.2\%) and Taeniidae $0.2 \%$. Silage feeding constitute a risk factor for the acquisition of coccidian ( $p$ : 0.03). It is concluded that the prevalence of helminthic and coccidial infections in Ubate municipality is high.
\end{abstract}

Keywords: prevalence, risk factors, sheep, Trichostrongylids, Eimeriidae.

\section{Resumo}

A produção de ovinos é considerada um importante setor de abastecimento de carne para consumo humano e contribui ao desenvolvimento das zonas rurais. As infecções gastrointestinais em ovinos incluem infecções por helmintos e coccidios, e para estabelecer medidas preventivas contra parasitas em rebanhos o conhecimento da epidemiologia é necessário. O objetivo deste estudo foi determinar a prevalência de infecções helmínticas e por coccidios em ovelhas de Ubaté - Colômbia pelo método de concentração Ritchie e identificar os fatores de risco (sexo, dieta, idade, condição fisiológica e condição antiparasitária) associados com a infecção. 400 amostras fecais foram coletadas usando o método de amostragem por conveniência. Os fatores de risco foram analisados por análise de regressão logística. O risco foi expresso com odds ratio (OR) usando um intervalo de confiança de 95\%. Epidemiologia descritiva e fatores de risco foram realizados com o software EpiInfo. A prevalência geral foi de 78.1\%. Diferentes famílias foram observadas Dictyocaulidae (43.5\%), Trichostrongylidae (32.7\%), Ascaridae (2.8\%), Trichiuridae (3\%), Chabertiidae (39.7\%), Fasciolidae (0.4\%), Eimeriidae (93.2\%) e 0.2\% Taeniidae. A alimentação com silagem é um fator de risco para a aquisição de coccídios (p: 0.03). Conclui-se que a prevalência de infecções por helmintos e coccidios, no município de Ubaté é alta.

Palavras-chave: prevalência, fatores de risco, ovinos, Tricostrongilideo, Eimeriidae. \section{B] M Brazilian Journal of Veterinary Medicine

How to cite: Pulido-Medellín, M. O., Chavarro-Tulcán, G. I., \& Díaz-Anaya, A. M. (2020). Prevalence and risk factors of gastrointestinal parasites insheep from Ubaté, Cundinamarca, Colombia. Brazilian Journal of Veterinary Medicine, 42, e098819. https://doi.org/10.29374/2527-2179.bjvm098819

\section{Financial support: None}

Conflict of interests: No conflict of interests declared concerning the publication of this article.

Received: August 06, 2018

Accepted: November 08, 2019

The study was carried out at Veterinary Parasitology Laboratory, Universidad Pedagógica y Tecnológica de Colombia, Tunja, Colombia.

\section{*Correspondence}

Adriana María Díaz-Anaya

Group of Research in Veterinary Medicine and Zootechnics - GIDIMEVETZ, Faculty of Veterinary Medicine and Zootechnics, Universidad Pedagógica y Tecnológica de Colombia - UPTC

Avenida Central del Norte 39-115 Zipcode 150001 - Tunja, Colombia E-mail: adrianamaria.diaz@uptc.edu.co
Copyright Pulido-Medellín et al. This is an Open Access article distributed under the terms of the Creative Commons Attribution Non-Commercial License which permits unrestricted non-commercial use, distribution, and reproduction in any medium provided the original work is properly cited. 


\section{Introduction}

In Colombia, the total sheep population is estimated at 1'423.274 million heads and Cundinamarca region has the $3.14 \%$ of the entire population. Despite the low population, sheep production is considered an important sector of meat supply for human consumption and contributes to development of the rural areas because is practiced mostly by subsistence farmers (Díaz-Anaya et al., 2017).

Breeding practices in sheep production can predispose the animals to risk of infection due to the limitation on the land available for grazing and the confined conditions in small areas which increases the chances, of spreading diseases among the sheep (Raza et al., 2014). Furthermore, studies have shown that some of sheep gastrointestinal parasites (GIP) are of public health importance because its transmission to human either by direct contact with sheep manure or indirectly through ingestion of contaminated food or water (Sultan et al., 2016).

The infections caused by helminth parasites are very common in ruminants worldwide but mainly they prefer areas with enough humidity for the development of free-living stages of their life cycle (Martínez-Valladares et al., 2013). In intensive breeding conditions accompanied by a high animal density and high productivity, coccidiosis can become an infection of significant economic importance in small ruminants (Chartier \& Paraud, 2012). Those infections represent a threat for the sheep productivity, as they cause blood and plasma proteins loss and in the gastrointestinal tract they cause, alterations in protein metabolism, mineral reduction, depression in the activity of some intestinal enzymes, diarrhea (Ensuncho-Hoyos et al., 2014).

Around the world, the reported gastrointestinal nematodes affecting sheep and goats include: Haemonchus, Trichostrongylus, Teladorsagia/Ostertagia, Strongyloides, Bunostomum, Nematodirus, Chabertia, Trichuris, Cooperia, Skrjabinema and Oesophagostomum, and the general prevalence estimate is 75.8\% (Asmare et al., 2016).On the other hand, the main species of coccidia in sheep are Eimeria ovinoidalis, E. crandallis, E. ahsata and E. parva in sheep (Souza et al., 2015).

In addition to establishing preventive measures against parasites in sheep flocks, a clear understanding of the epidemiology of the parasites in question is required. The aim of this study was to identify the intestinal parasitic infections prevalent in sheep from Ubaté, Colombia.

\section{Materials and methods}

\section{Study design}

A cross-sectional study was carried out to address the stated objectives. The target population consisted of sheep in Ubaté in the Cundinamarca region of Colombia. Ubatéis located in the Eastern Range with an area about $102 \mathrm{~km}^{2}$ and a sheep population of approximately 600. Rural areas, consisting primarily of houses, gardens and farms surround the city. Temperatures average $13^{\circ} \mathrm{C}$ and precipitation averages $768 \mathrm{~mm}$ (Rojas et al., 2010).

\section{Sample collection}

The study population consisted of 400 sheep. The database collected information on gender, age, feeding, physiological state and deworming plan. Researchers collected fecal samples using a convenience sampling method. At the time of collection, samples were placed in zip-lock bags, labeled with the sheep's number, and stored in ice packs in a cooler. They were then stored shortterm (1 day) at $4^{\circ} \mathrm{C}$ prior to microscopy.

\section{Sample analysis and microscopy}

All samples were processed using a qualitative centrifugation concentration technique, with formaldehyde and ether as the concentration media. Researchers examined the samples using bright-field microscopy with a 40x objective. Each observed cyst and egg were identified by its morphological characteristics.

\section{Statistical analysis of data}

Frequency, prevalence and a 95\% confidence interval of gastrointestinal parasites infection was established. These parameters were determined by sex (male, female), age (12 months; 
$>12 \leq 24$ months; $>24 \leq 36$ months; >36 $\leq 48$ months), and the difference between categories was analyzed using the chi-square test.

Risk factors like sex, type of feeding, age, physiological state and deworming state were analyzed by logistic regression analysis. Risk was expressed as an odds ratio (OR) with 95\% confidence interval. Descriptive epidemiology and risk factors were calculated using EpiInfo software.

\section{Ethics statement}

This study was conducted in accordance with the Resolution 8430/1993 from the Colombian Ministry of Health and Social Protection and the law 84/1989, which set standards for animal welfare during research. Researchers obtained permission from the sheep's owners before collecting fecal samples. The field studies excluded endangered or protected species.

\section{Results and discussion}

The high overall prevalence of GIP parasites (78.1\%) in this study indicates a very intense transmission across the 400 animals. Different families were observed Dictyocaulidae, Trichostrongylidae, Eimeriidae, Fasciolidae, Ascarididae, Trichuridae, Chabertiidae and Taeniidae. Eimeriidae was the most prevalent family, followed by Dictyocaulidae, Chabertiidae and Trichostrongylidae, the other families had a lower prevalence (Table 1).

The overall prevalence found in this study is similar to that found in Antioquia (Colombia) 86.6\% (Herrera et al., 2013), Cameroon 73.8\% (Mbuh et al., 2008) and Norway 73.3\% (Domke et al., 2013) but is different from that found in Egypt 50\% (Sultan et al., 2016) and Australia 18.1\% (Yang et al., 2014).

The quite high prevalence of parasites may be attributed to the free range husbandry of sheep in the study area, where animals are exposed to many potential sources of parasitic infection via contaminated pastures and water sources (Sultan et al., 2016). The husbandry of the animals in environments with low hygiene and high humidity facilitates the development of the life cycle of the parasites in great quantity and the grazing system, where there is no rotation of paddocks and all age groups graze together without differentiation, possibly increases the level of infection in the herds studied (Díaz-Anaya et al., 2017).

Table 1. General prevalence of gastrointestinal parasites in sheep from Ubaté, Cundinamarca, Colombia.

\begin{tabular}{lcc}
\hline \multicolumn{1}{c}{ Family } & $\mathbf{N}^{\circ}$ of positive animals $\mathbf{( n = 4 0 0 )}$ & Prevalence $\mathbf{( 9 5 \% ~ C I})^{*}$ \\
\hline Dictyocaulidae & 174 & $43.5 \%$ \\
Trichostrongylidae & 131 & $32.7 \%$ \\
Eimeriidae & 373 & $93.2 \%$ \\
Fasciolidae & 2 & $0.4 \%$ \\
Ascarididae & 11 & $2.8 \%$ \\
Trichuridae & 12 & $3 \%$ \\
Chabertiidae & 159 & $39.7 \%$ \\
Taeniidae & 1 & $0.2 \%$ \\
\hline
\end{tabular}

*significant difference $(\mathrm{P}<0.05)$. confidence interval $(\mathrm{Cl})$, Number $(\mathrm{N})$.

This high prevalence also puts in question the efficacy of different anthelmintics (Sales \& Love, 2016; Cintra et al., 2016). Low efficacy of the medicines may be attributed to the misuse of these drugs, dose, and frequency of application. This is because shepherds do not usually seek the veterinary supervision and they give these medicines as a routine regime (Sultan et al., 2016).

In addition, the lack of association between sex, physiological state and deworming practice with the presence of the parasites and the absence of these as a risk factors differ from the results found in other studies where females are assumed to be more heavily infected due to hormonal differences and stress during pregnancy (Raza et al., 2014) and young animals had more risk to acquire the lungworm (Borji et al., 2012). 
The coprological study revealed that Eimeria (93.2\%) predominated and similar findings were recorded in previous studies from Boyacá where the Eimeriidae family had the highest prevalence with 94.4\% (Pulido-Medellín et al., 2014) and 63\% (Díaz-Anaya et al., 2017). This high prevalence is significant because of coccidiosis has a great economic importance not only for the losses due to clinical disease (diarrhea) but also because of subclinical infections (poor weight gain in particular) (Chartier \& Paraud, 2012).

In this study it was found that the sheep supplemented with silage had more probability to become infected with some parasite than those who were supplemented with concentrate (OR: 0.4 p: 0.03), in agreement with Chartier \& Paraud (2012), who found that under-feeding and some aliments are likely to perturb the immune system and it is possible that the silage does not provides enough nutritional requirements.

It is important to feed the animal with quality food or concentrate that helps them maintain a good immunity system because even if good immunity does not lead to total exclusion of parasites, it does prevent clinical disease. As a consequence, a well-nourished lamb with only a moderate infection will be able to replace damaged tissue quickly and recover well, while at the same time acquiring immunity for the future (Taylor et al., 2011; Sargison, 2013).

Those results can also be due to the production system because infection intensity of oocysts is influenced by two factors: intensity of animal production and the coccidiosis carrier-state in dams, which are the main source of infection to young (Cai \& Bai., 2009). If animals are in a higher density, feces-urine fouled forage, sheep raised in confinement and semi-confinement conditions could be more heavily infected with coccidia than those grazing on pastures (Souza et al., 2015). In further studies is important to take into account the grazing conditions of the animals because it could be a risk factor.

It was found a Tricostrongilids prevalence of 32.7\% similar to those found in Boyacá where different studies have shown prevalences between 31.3\% and 47.4\% (Pulido-Medellín et al., 2014; Díaz-Anaya et al., 2014; Díaz-Anaya et al., 2017). In the other hand, in Cordoba (Colombia) a high prevalence of gastrointestinal Tricostrongilids was found (97.7\%); in coprocultures infective larvae (L3) of Haemonchus spp, Trichostrongylus spp and Cooperia spp, were identified, being the dominant genus Haemonchus spp with 40.8\% (Ensuncho-Hoyos et al., 2014).

In Antioquia nematode infection frequency for Haemonchus contortus 66.3\%, Trichostrongylus spp. 34.7\% and Ostertagia spp. 24.2\% were the most prevalent nematodes (Herrera et al., 2013).

In Cameroon, H. contortus was the most prevalent species with a prevalence of $94.2 \%$. The highest mean monthly intensity was obtained during the rainy season because with the onset of the rains, the environmental conditions become favorable for larval survival (Mbuh et al., 2008). In this study, the season was not take into account, thus it is important to consider it for further studies.

In Greece $47.6 \%$, where farms do not practice rotation of grazing, had higher odds of positivity for $H$. contortus, probably due to the accumulation of larvae (Kouam et al., 2014). In this study the rotation of grazing was not take into account but is an important factor for being considered.

Statistically significant differences were found among age and feeding in Dictyocaulidae family (Table 2). However, researchers didn't find an association between sex, physiological state and deworming practice with the presence of the parasites and the variables do not constitute a risk factor (Table 3). Dyctiocaulidae prevalence was 43.5\% similar to that found in Boyacá with 38.1\% (Díaz-Anaya et al., 2017) but higher than the 6.9\% found in Iran where younger animals had more risk to acquire the lungworm as well as males. D. filaria has a direct life cycle and takes less time to reach the infective stage and after ingestion, larvae can appear in the faeces within 5 weeks (Borji et al., 2012).

Chabertidae had a 39.7\% prevalence similar to that found in Spain with 22\% (MartínezValladares et al., 2013). This prevalence is important because the pathogenic effects of Chabertidae species in sheep consist in mucosal ulceration and local hemorrhage with protein loss into the gut and some reports claim that larvae and immature adults are blood suckers (Urban et al., 2014).

The families Fasciolidae (0.4\%), Trichuridae (3\%), Taeniidae (0.2\%) and Ascarididae (2.8\%) had a lower prevalence as well as reported in Boyacá where the families Fasciolidae (6.3\%), Trichuridae (5.7\%) and Taeniidae (0.3\%), had the lower prevalence (Díaz-Anaya et al., 2017).

The low prevalence of Fasciolidae family can be compared with the $0.2 \%$ found in Egypt (Elmonir et al., 2015). This low prevalence is important for the region because other studies in 
Table 2. Parasites families; positive prevalence rates and p value by sex, type of feeding, age, physiological state and deworming state.

\begin{tabular}{|c|c|c|c|c|c|c|c|c|c|c|c|c|c|c|c|c|}
\hline \multirow{2}{*}{ Factor } & \multicolumn{2}{|c|}{ Dictyocaulidae } & \multicolumn{2}{|c|}{ Trichostrongylidae } & \multicolumn{2}{|c|}{ Eimeriidae } & \multicolumn{2}{|c|}{ Fasciolidae } & \multicolumn{2}{|c|}{ Ascarididae } & \multicolumn{2}{|c|}{ Trichuridae } & \multicolumn{2}{|c|}{ Chabertiidae } & \multicolumn{2}{|c|}{ Taeniidae } \\
\hline & $\%$ & $\mathrm{p}$ & $\%$ & $\mathrm{p}$ & $\%$ & $\mathrm{p}$ & $\%$ & $\mathrm{p}$ & $\%$ & $\mathrm{p}$ & $\%$ & $\mathrm{p}$ & $\%$ & $\mathrm{p}$ & $\%$ & $\mathrm{p}$ \\
\hline \multicolumn{17}{|l|}{ Gender } \\
\hline Female & 59.6 & 3.1 & 36.4 & 0.3 & 84.5 & & 0.8 & 0.9 & 1.5 & 0.5 & 2.3 & & 41 & 0.7 & 0 & 0.6 \\
\hline Male & 38.2 & & 31.5 & & 96 & & 0.3 & & 3.2 & & 3.2 & & 39 & & 0.3 & \\
\hline \multicolumn{17}{|l|}{ Feeding } \\
\hline silage & 32.6 & 0 & 31 & 0.61 & 95.8 & & 0 & 0.7 & 3.1 & 0.9 & 3.6 & & 34.2 & 0.06 & 0.5 & 0.8 \\
\hline concentrate & 49.7 & & 33.6 & & 91.8 & & 0.6 & & 2.7 & & 2.7 & & 42.8 & & 0 & \\
\hline \multicolumn{17}{|l|}{ Age (years) } \\
\hline 1 & 51 & 0.01 & 33.7 & 0.8 & 89.3 & & 0.5 & 0.8 & 1.7 & 0.4 & 2.8 & & 38.2 & 0.7 & 0 & 0.7 \\
\hline 2 & 48.9 & 0 & 30.6 & 0.9 & 97.9 & & 0 & 0.5 & 3.1 & 0.5 & 2.1 & & 41.8 & 0.9 & 0 & 0.9 \\
\hline 3 & 34.5 & 0.03 & 38.1 & 0.4 & 94 & & 0 & 0.8 & 7.1 & 0.5 & 4.8 & & 46.4 & 0.4 & 1.2 & 0.7 \\
\hline 4 & 35.2 & 0.3 & 31.8 & 0.4 & 94.1 & & 0 & 0.7 & 3.5 & 0.2 & 3.5 & & 42.3 & 0.1 & 0 & 0.3 \\
\hline \multicolumn{17}{|l|}{$\begin{array}{l}\text { Physiological } \\
\text { state }\end{array}$} \\
\hline \multicolumn{17}{|l|}{ Female } \\
\hline pregnancy & 31 & 0.5 & 27.6 & 0.8 & 96.5 & 0.7 & 0 & 0.1 & 10.3 & 0.1 & 3.4 & 0.6 & 34 & 0.7 & 0 & 0.1 \\
\hline empty & 38.8 & & 32 & & 95.9 & & 0.2 & 0.3 & 2.7 & & 3.2 & & 39 & & 0 & \\
\hline \multicolumn{17}{|l|}{ Male } \\
\hline fattening & 59.2 & 0.9 & 39 & 0.2 & 84 & 0.9 & 0.8 & & 1.7 & 0.6 & 2.6 & 0.8 & 42 & 0.5 & 0 & 0.2 \\
\hline $\begin{array}{l}\text { breeding } \\
\text { animal }\end{array}$ & 62.5 & & 18.7 & & 87 & & 0 & & 0 & & 0 & & 31 & & 0.2 & \\
\hline \multicolumn{17}{|l|}{$\begin{array}{l}\text { Deworming } \\
\text { (in the } \\
\text { last three } \\
\text { months) }\end{array}$} \\
\hline No & 43 & 0.9 & 33 & 0.9 & 89 & & 1.1 & 0.2 & 2.8 & 0.8 & 2.8 & & 39 & 0.9 & 0 & 0.7 \\
\hline Yes & 43.6 & & 32.6 & & 95 & & 0 & & 2.8 & & 3.1 & & 40 & & 0.2 & \\
\hline
\end{tabular}

p: p value.

Table 3. Risk factors for the different families infection following analysis by flotation technique in sheeps from Ubaté - Colombia obtained by logistic regression analysis.

\begin{tabular}{|c|c|c|c|c|c|c|c|c|c|c|c|c|c|c|c|c|}
\hline \multirow{2}{*}{ Factor } & \multicolumn{2}{|c|}{ Dictyocaulidae } & \multicolumn{2}{|c|}{ Trichostrongylidae } & \multicolumn{2}{|c|}{ Eimeriidae } & \multicolumn{2}{|c|}{ Fasciolidae } & \multicolumn{2}{|c|}{ Ascarididae } & \multicolumn{2}{|c|}{ Trichuridae } & \multicolumn{2}{|c|}{ Chabertiidae } & \multicolumn{2}{|c|}{ Taeniidae } \\
\hline & OR & pvalue & OR & pvalue & OR & pvalue & OR & pvalue & OR & pvalue & OR & pvalue & OR & pvalue & OR & pvalue \\
\hline Sex & 2.5 & 0.07 & 1.1 & 0.8 & 0.3 & 0.2 & 0.1 & 0.4 & 0.2 & 0.1 & 0.5 & 0.6 & 0.7 & 0.5 & 1.5 & 0.9 \\
\hline Feeding & 0.6 & 0.07 & 1.1 & 0.7 & 0.4 & 0.03 & 1.9 & 0.06 & 0.7 & 0.7 & 1.3 & 0.6 & 0.6 & 0.05 & 7.7 & 0.1 \\
\hline Age & 0.9 & 0.7 & 1.1 & 0.7 & 0.8 & 0.2 & 2.3 & 0.3 & 0.8 & 0.4 & 0.9 & 0.8 & 1 & 0.8 & 0.7 & 0.6 \\
\hline $\begin{array}{l}\text { Physiological } \\
\text { state }\end{array}$ & 1.1 & 0.7 & 1.3 & 0.6 & 1.2 & 0.5 & 0.3 & 0.4 & 1.3 & 0.5 & 0.8 & 0.7 & 0.9 & 0.6 & 7 & 0.4 \\
\hline Deworming & 1.2 & 0.3 & 1.1 & 0.2 & 1.7 & 0.2 & 7 & 0.1 & 0.8 & 0.7 & 1.1 & 0.9 & 0.9 & 0.9 & 1.2 & 0.6 \\
\hline
\end{tabular}

OR: odds ratio, p: p value

Colombia, had reported high prevalences in Fasciola hepatica in cattle (Recalde-Reyes et al., 2014;

Giraldo Forero et al., 2016).

This parasite in particular produces high economic losses that include direct losses in the form of condemnation of the liver of slaughtered animals and carcasses weight losses at the slaughter (Uduak, 2014) or indirect as poor feed conversion, weight loss, slow fattening, reduced milk yield, reproductive failure and ultimately death (Biu et al., 2013). 
It is concluded that the prevalence of helminthic infections and coccidial infections in Ubaté city were high and significantly important in the region. This level of infection could be due to contamination in the environment, deficient deworming programs, the housing of the animals in environments with low hygiene and high humidity and the grazing system. Finally, prophylactic measures for coccidiosis are desirable where young animals are at risk of contracting infections from high stock concentration.

\section{References}

Asmare, K., Sheferaw, D., Aragaw, K., Abera, M., Sibhat, B., Haile, A., Kiara, H., Szonyi, B., Skjerve, E., \& Wieland, B. (2016). Gastrointestinal nematode infection in small ruminants in Ethiopia: a systematic review and meta-analysis. Acta Tropica, 160, 68-77. http://dx.doi.org/10.1016/j.actatropica.2016.04.016. PMid:27154584.

Biu, A., Paul, B., Konto, M., \& Ya'uba, A. (2013). Cross sectional and phenotypic studies on fasciolosis in slaughter cattle in Maiduguri. Journal of Agriculture and Veterinary Sciences, 5(2), 155-162.

Borji, H., Azizzadeh, M., Ebrahimi, M., \& Asadpour, M. (2012). Study on small ruminant lungworms and associated risk factors in northeastern Iran. Asian Pacific Journal of Tropical Medicine, 5(11), 853-856. http://dx.doi. org/10.1016/S1995-7645(12)60159-X. PMid:23146797.

Cai, K., \& Bai, J. (2009). Infection intensity of gastrointestinal nematodosis and coccidiosis of sheep raised under three types of feeding and management regims in Ningxia Hui Autonomous Region, China. Small Ruminant Research, 85(2-3), 111-115. http://dx.doi.org/10.1016/j.smallrumres.2009.07.013.

Chartier, C., \& Paraud, C. (2012). Coccidiosis due to Eimeria in sheep and goats, a review. Small Ruminant Research, 103(1), 84-92. http://dx.doi.org/10.1016/j.smallrumres.2011.10.022.

Cintra, M. C., Teixeira, V., Nascimento, L., \& Sotomaior, S. (2016). Lack of efficacy of monepantel against Trichostrongylus colubriformis in sheep in Brazil. Veterinary Parasitology, 216, 4-6. http://dx.doi.org/10.1016/j. vetpar.2015.11.013. PMid:26801587.

Díaz-Anaya, A., Arias-González, H., García-Corredor, D., \& Pulido-Medellín, M. (2014). Estimation of hematocrit packed cell volume and hemoglobin with the presence of Haemonchus sp. in sheep of Oicatá, Colombia. Revista Facultad Ciencias Veterinarias UCV, 55(1), 18-24.

Díaz-Anaya, A., Chavarro-Tulcán, G., Pulido-Medellín, M., García-Corredor, D., \& Vargas-Avella, J. (2017). Coproparasitological study in grazing sheep in Boyacá, Colombia. Revista de Salud Animal, 39(1), 1-8.

Domke, A. V., Chartier, C., Gjerde, B., Leine, N., Vatn, S., \& Stuen, S. (2013). Prevalence of gastrointestinal helminths, lungworms and liver fluke in sheep and goats in Norway. Veterinary Parasitology, 194(1), 40-48. http://dx.doi. org/10.1016/j.vetpar.2012.12.023. PMid:23298563.

Elmonir, W., Mousa, W., \& Sultan, K. (2015). The prevalence of some parasitic zoonoses in different slaughtered animal species at abattoir in the Mid-Delta of Egypt; with Special Reference to its Economic Implications. Alexandria Journal of Veterinary Sciences, 47(1), 97-103. http://dx.doi.org/10.5455/ajvs.204290.

Ensuncho-Hoyos, C., Castellano-Coronado, A., Maza-Ángulo, L., Bustamante-Yánez, M., \& Vergara-Garay, O. (2014). Prevalence and level of gastrointestinal nematode infection in sheep of hair in grazing in four municipalities of Cordoba, Colombia. Revista Científica FCV-LUZ, 14(5), 414-42O.

Giraldo Forero, J. C., Díaz Anaya, A. M., \& Pulido Medellín, M. O. (2016). Prevalence of Fasciola hepatica in cattle in the slaughterhouse of the municipality of Une, Cundinamarca, Colombia. Revista de Investigaciones Veterinarias del Perú, 27(4), 751-757. http://dx.doi.org/10.15381/rivep.v27i4.12572.

Herrera, L., Ríos, L., \& Zapata, R. (2013). Infection frequency of gastrointestinal nematode in goats and sheep of five municipalities in Antioquia. Revista Mvz Cordoba, 18(3), 3851-3860.

Kouam, M. K., Diakou, A., Kantzoura, V., Feidas, H., Theodoropoulou, H., \& Theodoropoulos, G. (2014). An analysis of seroprevalence and risk factors for parasitic infections of economic importance in small ruminants in Greece. Veterinaryjournal (London, England: 1997), 202(1), 146-152. http://dx.doi.org/10.1016/j.tvjl.2014.07.011. PMid:25155306.

Martínez-Valladares, M., Robles-Pérez, D., Martínez-Pérez, J., Cordero-Pérez, C., Famularo, M., Fernández-Pato, N., González-Lanza, C., Castañón-Ordóñez, L., \& Rojo-Vázquez, F. (2013). Prevalence of gastrointestinal nematodes and Fasciola hepatica in sheep in the northwest of Spain: relation to climatic conditions and/or man-made environmental modifications. Parasites \& Vectors, 6(1), 282. http://dx.doi.org/10.1186/1756-33056-282. PMid:24289489.

Mbuh, J. V., Ndamukong, K., Ntonifor, N., \& Nforlem, G. (2008). Parasites of sheep and goats and their prevalence in Bokova, a rural area of Buea Sub Division, Cameroon. Veterinary Parasitology, 156(3-4), 350-352. http:// dx.doi.org/10.1016/j.vetpar.2008.06.021. PMid:18707810.

Pulido-Medellín, M., García-Corredor, D., Díaz-Anaya, A., \& Andrade-Becerra, R. (2014). Screening of gastrointestinal parasites on small sheep exploitations from the municipality of Toca, Colombia. Revista de Salud Animal, 36(1), 1-5.

Raza, M., Younas, M., \& Schlecht, E. (2014). Prevalence of gastrointestinal helminths in pastoral sheep and goat flocks in the Cholistan desert of Pakistan. Journal of Animal and Plant Sciences, 24(1), 127-134. 
Recalde-Reyes, D. P., Padilla Sanabria, L., Giraldo Giraldo, M. I., Toro Segovia, L. J., Gonzalez, M. M., \& Castaño Osorio, J. C. (2014). Prevalence of Fasciola hepatica in humans and cattle in the department of QuindioColombia 2012-2013. Infectio, 18(4), 53-157. http://dx.doi.org/10.1016/i.infect.2014.09.001.

Rojas, E., Arce, B., Peña, A., Boshell, F., \& Ayarza, M. (2010). Quantization and interpolation of local trends in temperature and precipitation in the high Andean areas of Cundinamarca and Boyacá (Colombia). Corpoica Ciencia y Tecnología Agropecuaria, 11(2), 173-182. http://dx.doi.org/10.21930/rcta.vol11_num2_art:209.

Sales, N., \& Love, S. (2016). Resistance of Haemonchus sp. to monepantel and reduced efficacy of a derquantel/ abamectin combination confirmed in sheep in NSW, Australia. Veterinary Parasitology, 228, 193-196. http:/l dx.doi.org/10.1016/j.vetpar.2016.08.016. PMid:27692326.

Sargison, N. (2013). Understanding the epidemiology of gastrointestinal parasitic infections in sheep: What does a faecal helminth egg count tell us? Small Ruminant Research, 110(2-3), 78-81. http://dx.doi.org/10.1016/j. smallrumres.2012.11.008.

Souza, L. E., Cruz, J. F., Teixeira Neto, M. R., Albuquerque, G. R., Melo, A. D., \& Tapia, D. M. (2015). Epidemiology of Eimeria infections in sheep raised extensively in a semiarid region of Brazil. Revista Brasileira de Parasitologia Veterinária, 24(4), 410-415. http://dx.doi.org/10.1590/S1984-29612015070. PMid:26648007.

Sultan, K., Elmonir, W., \& Hegazy, Y. (2016). Gastrointestinal parasites of sheep in Kafrelsheikh governorate, Egypt: Prevalence, control and public health implications. Beni-Suef University Journal of Basic and Applied Sciences, 5(1), 79-84. http://dx.doi.org/10.1016/j.bjbas.2015.12.001.

Taylor, M. A., Marshall, R., Marshall, J., Catchpole, J., \& Bartram, D. (2011). Dose-response effects of diclazuril against pathogenic species of ovine coccidia and the development of protective immunity. Veterinary Parasitology, 178(1-2), 48-57. http://dx.doi.org/10.1016/j.vetpar.2010.12.024. PMid:21232870.

Uduak, A. (2014). Incidence of bovine fasciolosis and its economic implications at trans-amadi abattoir Port Harcourt, Nigeria. Acta Parasitologica Globalis, 5(3), 206-209. http://dx.doi.org/10.5829/idosi.apg.2014.5.3.85139.

Urban, J., Tauchen, J., Langrova, I., \& Kokoska, L. (2014). In vitro motility inhibition effect of Czech medicinal plant extracts on Chabertia ovina adults. Journal of Animal \& Plant Sciences, 21(2), 3293-3302.

Yang, R., Jacobson, C., Gardner, G., Carmichael, I., Campbell, A., \& Ryan, U. (2014). Longitudinal prevalence, oocyst shedding and molecular characterization of Eimeria species in sheep across four states in Australia. Experimental Parasitology, 145, 14-21. http://dx.doi.org/10.1016/j.exppara.2014.06.018. PMid:25033746. 